\title{
EFISIENSI PENGGUNAAN FAKTOR PRODUKSI PADA USAHATANI JAGUNG \\ DI KECAMATAN REMBOKEN KABUPATEN MINAHASA \\ (Studi Perbandingan Peserta dan Bukan Peserta Sekolah Lapang Pengelolaan Tanaman Terpadu)
}

\author{
Carolina B.D. Pakasi \\ L. Pangemanan \\ Juliana R. Mandei \\ Nineteen N.I. Rompas
}

\begin{abstract}
The study was designed to analyze the efficiency of production factors between the program and who do not follow SLPTT program. This study starts from November to December 2010. Data obtained from primary and secondary data. Primary data obtained from interviews using a questionnaire to cosumers. Sampling was done by using the method of Sampling Cluster, specifically 3 farmers groups program participants SLPTT and 3 farmers group who are not participants SLPTT program. The analytical tool used is regression analysis Cobb-Douglas model using the program Minitab 15.

Results showed that technically, the efficient use of production factors of land, urea fertilizer, seed, labor and herbicides by farmers SLPTT participants and not participants are the same. unless the use of fertilizers ponska. Land use has not been efficient because of the percentage increase in corn production is higher than the percentage increase in land $(\mathrm{Ep}>1)$, the use of urea fertilizer and seed are efficient $(0<\mathrm{Ep}<1)$ while the use of production factors labor and herbicides are not efficient because the additional factor of production will reduce the production of maize $(\mathrm{Ep}<0)$. The use of factors of production of fertilizers by farmers participating ponska SLPTT already efficient while the use of fertilizer by farmers rather than participants SLPTT inefficient.

Economically, the efficient use of production factors by both participants and non-participant farmers SLPTT is the same except for the use of fertilizers ponska. The use of production factors land, urea fertilizer, and seed has not been efficient, while the use of production factors labor and herbicides are not efficient. The use of factors of production of fertilizers by farmers participating Phonska SLPTT has not been efficient while the use of factors of production by non-participant farmers SLPTT inefficient.
\end{abstract}

Keywords: Efficiency, Factors of production, Corn farming

\section{PENDAHULUAN}

\section{Latar Belakang}

Salah satu komoditi tanaman pangan yang dapat mengambil peran dalam pembangunan sektor pertanian adalah komoditi jagung. Di Indonesia, Jagung merupakan komoditas pangan kedua setelah padi dan sumber kalori atau makanan pengganti beras disamping itu juga sebagai pakan ternak. Kebutuhan jagung akan terus meningkat dari tahun ketahun sejalan dengan peningkatan taraf hidup ekonomi masyarakat dan kemajuan industri pakan ternak sehingga perlu upaya peningkatan produksi melalui sumber daya manusia dan sumber daya alam, ketersediaan lahan maupun potensi hasil dan teknologi.

Salah satu daerah produksi jagung di Kabupaten Minahasa adalah Kecamatan Remboken. Perkembangan komoditi jagung di Kecamatan Remboken pada tahun 2008 mencapai 7616 ton dengan luas panen 1.263 ha dan produktivitas 6,03 ton/ha yang tersebar dibeberapa desa. Data secara lengkap disajikan dalam Tabel 1.

Kecamatan Remboken merupakan salah satu tempat yang diberi kesempatan untuk merealisasikan program tersebut, tapi tidak semua petani bisa mengikuti program ini. Program ini bertujuan untuk meningkatkan kemandirian pangan nasional 
melalui usaha peningkatan produksi pangan nasional, khususnya padi, jagung dan kedelai. Pengembangan SLPTT dilakukan dengan memberi pengajaran pada petani mengenai pengendalian pemberian benih, pupuk, pengendalian hama terpa$\mathrm{du}$, sekolah lapang iklim dan teknologi budidaya (Apriyantono, 2008).

Tabel 1. Luas Panen, produksi dan Produktivitas Jagung di Kecamatan Remboken Tahun 2008

\begin{tabular}{|l|c|c|c|}
\hline \multicolumn{1}{|c|}{ Desa } & $\begin{array}{c}\text { Luas } \\
\text { Panen } \\
\text { (ha) }\end{array}$ & $\begin{array}{c}\text { Produksi } \\
\text { (ton) }\end{array}$ & $\begin{array}{c}\text { Produktivitas } \\
\text { (ton/ha) }\end{array}$ \\
\hline Pulutan & 95 & 504 & 5,30 \\
\hline Sinuian & 211 & 428 & 2,02 \\
\hline Kaima & 96 & 416 & 4,33 \\
\hline Parepey & 135 & 800 & 5,92 \\
\hline Kasuratan & 164 & 1828 & 11,14 \\
\hline Sendangan & 34 & 324 & 9,52 \\
\hline Timu & 63 & 368 & 5,84 \\
\hline Tampusu & 158 & 1000 & 632 \\
\hline Talikuran & 89 & 624 & 7,01 \\
\hline Paslaten & 70 & 636 & 9,08 \\
\hline Leleko & 154 & 688 & 4,46 \\
\hline Jumlah & 1263 & 7616 & 6,03 \\
\hline
\end{tabular}

Sumber: BPS SULUT

Tersedianya sarana atau faktor produksi tidak selamanya memberikan produksi yang dapat menguntungkan petani. Sebab sering ditemukan penggunaan faktor produksi oleh petani tidak lagi sesuai dengan kebutuhan skala petani. Dalam proses produksi, untuk memperoleh keuntungan maksimal maka petani harus mengadakan pemilihan penggunaan faktor produksi secara tepat, mengkombinasikan secara optimal dan efisien. Namun pada kenyataannya masih baanyak petani yang belum memahami bagaimana faktor produksi tersebut digunakan secara efisien. Oleh karena itu, perlu dilakukan penelitian mengenai analisis efisiensi penggunaan faktor - faktor produksi.

\section{Perumusan Masalah}

Berdasarkan uraian diatas, maka yang menjadi rumusan masalah dalam penelitian ini adalah:
1. Apakah penggunaan faktor produksi pada usahatani jagung sudah efisien.

2. Apakah ada perbedaan tingkat efisiensi penggunaan faktor - faktor produksi antara yang mengikuti program SLPTT dan yang tidak.

\section{Tujuan dan Manfaat}

Tujuan yang ingin dicapai adalah untuk:

1. Menganalisis efisiensi penggunaan faktorfaktor produksi yang diterapkan petani dalam usahatani jagung.

2. Membandingkan efisiensi penggunaan faktorfaktor produksi antara yang mengikuti program SLPTT dan yang tidak mengikuti program.

Manfaat dari penelitian ini adalah:

1. Memberikan informasi dalam pengelolaaan usahatani jagung untuk memanfaatkan faktorfaktor produksi yang dapat memberikan hasil yang optimal.

2. Sebagai bahan informasi bagi peneliti selanjutnya.

\section{METODE PENELITIAN}

\section{Metode Pengumpulan Data}

Metode yang digunakan dalam penelitian ini adalah metode studi kasus, dengan menggunakan data primer dan data sekunder. Data primer diperoleh dari wawancara langsung pada petani responden, sedangkan data sekunder diambil dari instansi - instansi yang terkait dengan penelitian ini.

\section{Metode Pengambilan Sampel}

Dalam penelitian ini terdiri dari 2 populasi yaitu peserta program Sekolah Lapang Pengelolaan Tanaman Terpadu (SLPTT) dan bukan peserta. Masing - masing populasi terdiri dari kelompokkelompok tani. Pengambilan sampel dilakukan dengan menggunakan metode Cluster Sampling. Dengan cara memisahkan populasi yang ada,. Dari masing-masing populasi ditarik 3 kelompok tani secara acak sebagai sampel. Semua petani jagung yang masuk kedalam kelompok tani yang terpilih itulah yang menjadi sampel. 


\section{Konsep Pengukuran Variabel}

Variabel-variabel yang diukur serta digunakan dalam penelitian ini adalah:

1. Produksi ( $\mathrm{kg} / \mathrm{musim}$ tanam): Jagung yang dihasilkan dalam satu kali musim tanam. Sedangkan harga produksi dinyatakan dalam rupiah per kilogram.

2. Luas lahan (ha): Lahan yang ditanami jagung. Dan harga lahan dinilai berdasarkan harga sewa lahan selama satu kali musim tanam dalam rupiah per hektar..

3. Jumlah Tenaga kerja (HOK), yaitu jumlah tenaga kerja yang digunakan dalam satu kali musim tanam (Setara hari kerja pria). Sedangkan harga tenaga kerja dinilai berdasarkan upah per hari.

4. Jumlah Pupuk Urea (kg): Jumlah pupuk yang digunakan dalam satu kali musim tanam. Dan harga pupuk dalam rupiah per kilogram.

5. Jumlah Pupuk Phonska (kg): Jumlah pupuk yang digunakan dalam satu kali musim tanam. Dan harga pupuk dalam rupiah per kilogram.

6. Jumlah Benih (kg): Jumlah benih yang digunakan dalam satu kali musim tanam. Dan harga benih dalam rupiah per kilogram.

7. Jumlah Pestisida (ltr): Jumlah pestisida yang digunakan dalam pemberantasan hama dan penyakit. Dan harga pestisida dalam rupiah per liter.

\section{Analisis Data}

Analisis data menggunakan analisis regresi model Cobb- Douglass. Untuk melihat pengaruh masing-masing input faktor terhadap hasil produksi. Dengan persamaan sebagai berikut:

$$
\begin{aligned}
\operatorname{Ln} Y i= & \operatorname{Ln} \beta_{0}+\beta_{1} \operatorname{LnX}_{1}+\beta_{2} \operatorname{LnX}_{2}+\beta_{3} \operatorname{LnX} X_{3}+ \\
& \beta_{4} \operatorname{LnX}_{4}+\beta_{5} \operatorname{LnX}_{5}+\beta_{6} \operatorname{LnX}_{6}+\beta_{7} \mathrm{D}+ \\
& \beta_{8} \mathrm{DLnX}_{1}+\beta_{9} \mathrm{DLnX}_{2}+\beta_{10} \mathrm{DLnX}_{3}+
\end{aligned}
$$

Dimana:

$\mathrm{Yi}=$ Produksi Jagung $(\mathrm{kg})$

$\mathrm{X}_{1}=$ Luas lahan (ha)

$\mathrm{X}_{2}=$ Jumlah tenaga kerja $(\mathrm{HOK})$

$\mathrm{X}_{3}=$ Jumlah Pupuk Urea $(\mathrm{kg} / \mathrm{ha})$

$\mathrm{X}_{4}=$ Jumlah Pupuk Phonska $(\mathrm{kg} / \mathrm{ha})$

$\mathrm{X}_{5}=$ Jumlah Benih $(\mathrm{kg} / \mathrm{ha})$

$\mathrm{X}_{6}=$ Jumlah Pestisida (ltr/ha) $\beta_{1}-\beta_{21}=$ Koefisien Regresi variabel-variabel

$\mathrm{D} \quad=1$, jika peserta program

0 , jika bukan peserta program

Untuk menguji keberartian masing-masing parameter regresi pada model diatas dilakukan dengan menggunakan Uji T. Dengan formula:

$$
\mathrm{T}=\frac{\beta \mathrm{i}}{\mathrm{S} \beta \mathrm{i}}
$$

Jika dalam pengujian, $\beta_{7}-\beta_{11}$ berbeda nyata dari 0 (nol) maka tingkat efisiensi masing - masing faktor produksi dari peserta program berbeda dengan yang bukan peserta.

Efisiensi teknis dapat diketahui melalui elastisitas produksi, dalam persamaan $\mathrm{Ep}=$ bi. Elastisitas produksi adalah persentase perubahan dari output sebagai akibat dari persentase perubahan dari input (Soekartawi 1994)

Elastisitas produksi dapat ditulis sebagai berikut:

$$
\begin{aligned}
\mathrm{Ep} & =\frac{\delta \mathrm{Y} / \mathrm{y}}{\delta \mathrm{Xi} / \mathrm{Xi}} \\
& =\frac{\delta Y}{\delta X i} \cdot \frac{X i}{Y} \\
& =\mathrm{bi} \cdot \frac{X i}{Y} \cdot \frac{Y}{X i} \\
& =\mathrm{bi}
\end{aligned}
$$

Dimana:

1. $\mathrm{EP}=1$ : bila produk rata-rata (AP) mencapai maksimum. (AP=MP).

2. $\mathrm{EP}=0$; bila produk marginal $(\mathrm{MP})=0$, pada saat AP menurun.

3. EP>1: bila produksi total (TP) menaik dan produksi rata-rata (AP) juga naik.

4. $0<$ Ep $<1$ : baik produksi marginal maupun produksi rata-rata mengalami penurunan. Namun demikian nilai keduanya masih positif. Daerah ini merupakan daerah produksi yang rasional atau efisien karena pada daerah ini akan tercapai tingkat penggunaan faktor-faktor produksi secara optimum.

5. Ep $<0$ : perusahaan tidak mungkin melanjutkan produksi, karena penambahan input faktor justru menurunkan produksi total. Perusahan 
akan mengalami kerugian. Pada daerah ini pemakaian faktor produksi sudah tidak efisien lagi dan disebut daerah irasional.

Efisiensi penggunaan faktor produksi dapat dihitung dengan menggunakan efisiensi harga yaitu Nilai produk marginal input (NPMXi) sama dengan Harga input (PXi). Dengan menggunakan rumus:

$$
\begin{aligned}
& \frac{b i Y \cdot P Y}{X}=P X \\
& \text { NPMXi }=\mathrm{PXi}
\end{aligned}
$$

\section{Dimana:}

bi : elastisitas produksi

Y : produksi rata-rata

$\mathrm{X}$ : faktor produksi rata-rata

PY : harga produksi rata-rata

PX : harga faktor-faktor produksi rata-rata

\section{DESKRIPSI WILAYAH PENELITIAN}

\section{Letak dan Luas Wilayah}

Secara geografis Kecamatan Remboken berada di wilayah Kabupaten Minahasa yang berada pada ketinggian 750-1500m diatas permukaan laut dengan suhu maksimum $25^{\circ} \mathrm{C}$ dan suhu minimum $15^{\circ} \mathrm{C}$. Kecamatan Remboken terletak di daerah pesisir Tondano dengan batas-batas wilayah sebagai berikut:

- Utara : Kecamatan Tondano Selatan

- Timur : Danau Tondano dan Kecamatan Eris

- Selatan : Kecamatan Kakas, Tompaso, dan Kawangkoan

- Barat : Kecamatan Sonder, Tomohon Selatan Jarak ke ibukota Kabupaten Minahasa \pm 15 km yang dapat ditempuh dengan waktu \pm 15 menit, dan jarak ke ibukota Propinsi Sulawesi Utara berada dalam kondisi baik sehingga memudahkan penduduk dari dan menuju Kecamatan Remboken. Luas wilayah seluruh Kecamatan Remboken adalah 3.880 ha, yang terbagi dalam 11 desa. Luas pemukiman 206 ha, luas sawah $285 \mathrm{Ha}$, luas perladangan 2.685 ha, luas hutan lindung 63 ha, luas tanah Negara 215 ha.

\section{Sekolah Lapang Pengelolaan Tanaman Terpadu (SLPTT)}

Di Kecamatan Remboken terdapat 43 kelompok tani. 22 kelompok tani merupakan peserta program Sekolah Lapang Pengelolaan Tanaman Terpadu (SLPTT) sedangkan 21 kelompok tani bukan peserta program.

Program Sekolah Lapang Pengelolaan Tanaman Terpadu (SLPTT) di Kecamatan Remboken telah diterapkan sejak tahun 2008. Syarat untuk menjadi peserta dari program ini yaitu harus ada kelompok tani, kelompok tani tersebut aktif dalam kegiatan usahatani dan memenuhi administrasi yang ada seperti harus ada NPWP (Nomor Pokok Wajib Pajak) dan sertifikat kelompok tani.

Kelompok tani yang menjadi peserta dari program SLPTT ini terdiri dari 15-20 orang dan usahataninya adalah padi dan jagung. Program ini bertujuan untuk meningkatkan kemandirian pangan nasional melalui usaha peningkatan produksi pangan nasional.

Pengembangan SLPTT dilakukan dengan memberi pengajaran pada petani mengenai pengendalian pemberian benih, pupuk, pengendalian hama terpadu, dan teknologi budidaya. Selain mendapat pengajaran tentang berbagai keterampilan dan pengetahuan, peserta juga mendapatkan bantuan yaitu bantuan benih dan pupuk. Masingmasing kelompok tani diberikan bantuan benih dan pupuk (urea dan phonska). Bantuan tersebut diberikan kepada ketua kelompok tani kemudian dibagikan secara merata kepada anggota-anggota kelompok tani.

Benih yang direkomendasikan oleh penyuluh adalah benih jenis hibrida, sedangkan pupuk yaitu pupuk phonska dan pupuk urea. Anjuran yang diberikan kepada petani peserta program yaitu:

$\begin{array}{ll}\text { Benih } & : 15-20 \mathrm{~kg} / \mathrm{ha} \\ \text { Pupuk phonska } & : 300 \mathrm{~kg} / \mathrm{ha} \\ \text { Pupuk Urea } & : 100 \mathrm{~kg} / \mathrm{ha}\end{array}$




\section{HASIL DAN PEMBAHASAN}

\section{Keadaan Usahatani}

1) Lahan

Luas lahan yang diusahakan petani bervariasi antara $0,25-10$ ha, dan lahan yang dikelola petani responden ada yang milik sendiri dan ada yang milik orang lain (penggarap). Jumlah petani menurut strata luas lahan seperti terlihat pada Tabel.2.

Tabel 2 menunjukan bahwa luas lahan yang paling banyak dikelola petani responden peserta program yaitu berkisar antara $0,51-1$ ha sebanyak 29 orang, dan yang bukan peserta program yaitu $\leq$ 0,5 ha sebanyak 23 orang. Rata-rata luas lahan pada petani responden peserta program yaitu 1,51 ha dan pada petani responden bukan peserta program yaitu 1,16 ha.

Tabel 2. Jumlah Petani Responden Peserta dan $\mathrm{Bu}-$ kan Peserta Program SLPTT menurut Strata Luas Lahan di Kecamatan Remboken

\begin{tabular}{|c|c|c|c|}
\hline \multirow{2}{*}{ No. } & \multirow{2}{*}{$\begin{array}{c}\text { Luas Lahan } \\
\text { (ha) }\end{array}$} & \multicolumn{2}{|c|}{ Jumlah (orang) } \\
\cline { 3 - 4 } & $\leq 0.5$ & Peserta & Bukan Peserta \\
\hline 1 & - & 23 \\
\hline 2 & $0.51-1$ & 29 & 20 \\
\hline 3 & $1.01-2$ & 8 & 3 \\
\hline 4 & $2.01-4$ & 2 & 5 \\
\hline 5 & $>4$ & 3 & 1 \\
\hline & Jumlah & 42 & 52 \\
\hline
\end{tabular}

Sumber: Diolah dari data primer, 2010

\section{2) Benih}

Benih yang digunakan petani ada 2 jenis yaitu benih Hibrida dan Manado Kuning. Bagi petani responden yang merupakan peserta program menggunakan jenis benih hibrida sedangkan petani responden yang bukan peserta program menggunakan jenis benih manado kuning. Secara kualitatif, penggunaan benih pada petani yang bukan peserta program SLPTT lebih tinggi daripada petani peserta program.
3) Pupuk

Semua responden melakukan pemupukan dengan pupuk buatan terutama pupuk Urea dan Phonska. Dimana jumlah takaran pupuk masih beragam yakni pupuk urea $50-600 \mathrm{~kg} / \mathrm{ha}$ atau ratarata $194.47 \mathrm{~kg} / \mathrm{ha}$ dan Pupuk phonska 30-600 $\mathrm{kg} /$ ha atau rata-rata $153.25 \mathrm{~kg} / \mathrm{ha}$. Secara kualitatif, penggunaan pupuk khususnya pupuk urea pada petani peserta program SLPTT lebih tinggi daripada petani yang bukan peserta program. Dan penggunaan pupuk phonska pada petani peserta program SLPTT juga lebih tinggi daripada petani yang bukan peserta program.

\section{4) Herbisida}

Penggunaan herbisida umumnya tergantung dengan keadaan gulma di ladang jagung. Secara kualitatif, penggunaan herbisida pada petani yang bukan peserta program SLPTT lebih tinggi dibandingkan dengan penggunaan pestisida pada petani peserta.

\section{5) Tenaga kerja}

Tenaga kerja yang digunakan dalam usahatani petani responden adalah tenaga kerja dalam keluarga dan luar keluarga. Tenaga kerja tersebut terdiri dari tenaga kerja pria, wanita, ternak dan mesin. Dimana tenaga kerja ini dikonversikan ke setara hari kerja pria berdasarkan upah. Upah tenaga kerja pria bervariasi antara Rp.50.000Rp.75.000 per hari, upah tenaga kerja wanita antara Rp.40.000-Rp.60.000 per hari, upah sewa ternak Rp.100.000-Rp.200.000 per hari dan sewa mesin Rp.250.000-Rp.800.000 per hari. Secara kualitatif, penggunaan tenaga kerja pada petani peserta program SLPTT lebih tinggi dibandingkan dengan petani yang bukan peserta program.

Perbandingan penggunaan faktor-faktor produksi antara peserta dan bukan peserta SLPTT dapat dilihat pada Tabel 3. 
Tabel 3. Rekapitulasi Penggunaan Faktor-faktor Produksi pada Usahatani Jagung Peserta dan Bukan Peserta Program SLPTT di Kecamatan Remboken

\begin{tabular}{|c|l|c|c|}
\hline \multirow{2}{*}{ No. } & \multirow{2}{*}{ Faktor Produksi } & \multicolumn{2}{|c|}{ Rata-rata } \\
\cline { 3 - 4 } & & Peserta & $\begin{array}{c}\text { Bukan } \\
\text { Peserta }\end{array}$ \\
\hline 1 & Luas Lahan (ha) & 1,512 & 1,158 \\
\hline 2 & Tenaga Kerja (HOK) & 70,94 & 61,94 \\
\hline 3 & Pupuk Urea (kg) & 194,13 & 131,8 \\
\hline 4 & Pupuk Phonska (kg) & 173,2 & 113,3 \\
\hline 5 & Benih (kg) & 15,43 & 30,63 \\
\hline 6 & Herbisida (ltr) & 4,59 & 6,15 \\
\hline
\end{tabular}

Sumber: Diolah dari data primer, 2010

\section{Analisis Fungsi Produksi Jagung}

Untuk mengetahui pengaruh dari masingmasing faktor produksi pada petani peserta program SLPTT digunakan analisis regresi. Berdasarkan hasil analisis regresi diperoleh model hubungan antara luas lahan, tenaga kerja, pupuk urea, pupuk phonska, benih dan herbisida untuk yang peserta program SLPTT, sebagai berikut:

\section{$\mathrm{Y}=4,15+1,33 \mathrm{Ln}$ Luas lahan - 0,065 Ln TK + 0,156 Ln Pupuk Urea + 0,607 Ln Pupuk Phonska $+0,101$ Ln Benih + 0,178 Ln Herbisida}

Model tersebut menunjukan bahwa, naiknya luas lahan cenderung menaikkan produksi. Hasil pengujian statistik menunjukkan pengaruh luas lahan terhadap produksi sangat nyata $(\mathrm{P}=0,000)$. Dimana naiknya luas lahan sebesar $1 \%$ akan menaikkan produksi sebesar $1,33 \%$. Tapi dalam hasil analisis terlihat bahwa tingkat penggunaan faktor produksi lahan belum efisien secara teknis. Ratarata penggunaan luas lahan pada petani responden adalah 1,512 ha.

Faktor produksi benih cenderung menaikkan produksi. Walaupun secara statistik menunjukkan pengaruh benih terhadap produksi tidak nyata $(\mathrm{P}=0,722)$ namun hasil analisis menunjukkan bahwa penggunaan faktor produksi benih sudah efisien secara teknis. Dimana naikknya penggunaan benih sebesar $1 \%$ akan menaikkan produksi sebesar $0,101 \%$. Rata-rata penggunaan benih pada petani responden ialah 15,43 kg/ha, jika dibandingkan dengan anjuran penggunaan benih pada analisis usahatani jagung oleh Danarti Dkk yaitu sebanyak $56 \mathrm{~kg} / \mathrm{ha}$, hal ini berari bahwa penggunaan benih masih berada dibawah daripada anjuran. Jadi benih masih bisa ditambah. Sedangkan menurut anjuran yang diberikan oleh penyuluh yaitu $15-20 \mathrm{~kg} / \mathrm{ha}$, ini berarti penggunaan benih sudah sesuai anjuran tapi masih bisa ditambah untuk mendapatkan hasil yang lebih baik. Hal ini terjadi karena petani hanya bergantung pada bantuan yang diberikan oleh pemerintah. Sedangkan tujuan dari pemberian bantuan ini adalah agar supaya petani (khususnya yang hanya mempunyai modal kecil) bisa

Faktor produksi tenaga kerja menunjukkan pengaruh yang negatif terhadap produksi $(\mathrm{P}=$ $0,556)$. Dimana naiknya tenaga kerja sebesar $1 \%$ akan mengurangi produksi sebesar 0,065\%. Hasil analisis menunjukkan bahwa tingkat penggunaan faktor produksi tenaga kerja sudah tidak efisien secara teknis. Rata-rata penggunaan tenaga kerja pada petani responden yaitu 70,94 HOK. Jika dibandingkan dengan anjuran penggunaan tenaga kerja yang ada pada analisis usahatani jagung oleh Danarti dkk yaitu sebesar $57 \mathrm{HOK}$, ini berarti penggunaan tenaga kerja pada usahatani jagung di Kecamatan Remboken relatif sudah berlebihan.

Faktor produksi pupuk khususnya pupuk urea cenderung menaikkan produksi. Walaupun secara statistik menunjukkan pengaruh pupuk urea terhadap produksi tidak nyata $(\mathrm{P}=0,231)$ namun ada kecenderungan bahwa penggunaannya sudah efisien. Dimana naiknya penggunaan pupuk urea sebesar $1 \%$ akan menaikkan produksi sebesar $0,156 \%$. Hasil analisis menunjukkan bahwa tingkat penggunaan pupuk urea sudah efisien secara teknis. Rata-rata penggunaan pupuk urea yaitu 194,13 $\mathrm{kg} / \mathrm{ha}$, jika dibandingkan dengan anjuran penggunaan pupuk urea pada analisis usahatani jagung oleh Danarti dkk yaitu sebesar $150 \mathrm{~kg} / \mathrm{ha}$, hal ini berarti penggunaan pupuk urea pada petani responden sudah melebihi dari anjuran yang diberikan. Sedangkan menurut anjuran yang diberikan penyuluh yaitu $100 \mathrm{~kg} / \mathrm{ha}$, ini berarti penggunaan pupuk urea sudah melebihi dari anjuran yang diberikan.

Faktor produksi pupuk khususnya pupuk phonska cenderung menaikkan produksi. Hasil pengujian statistik menunjukkan pengaruh penggunaan pupuk phonska terhadap produksi sangat nya- 
ta $(\mathrm{P}=0,000)$. Naiknya penggunaan pupuk phonska sebesar $1 \%$ akan menaikkan produksi sebesar $0,607 \%$. Hasil analisis menunjukkan bahwa tingkat penggunaaan pupuk phonska sudah efisien secara teknis. Rata-rata penggunaan pupuk phonska pada petani responden yaitu 173,2 kg/ha. Jika dibandingkan dengan anjuran yang diberikan oleh penyuluh yaitu $300 \mathrm{~kg} / \mathrm{ha}$, hal ini berarti penggunaan pupuk phonska pada petani responden masih dibawah daripada anjuran. Jadi penggunaan pupuk phonska masih bisa ditambah. Faktor produksi herbisida cenderung menaikkan produksi. Dalam pengujian secara statistik menunjukkan pengaruh herbisida terhadap produksi tidak nyata $(\mathrm{P}=0,247)$ namun ada kecenderungan bahwa penggunaannya sudah efisien. Dimana naiknya penggunaan herbisida sebesar $1 \%$ akan menaikkan produksi sebesar $0,178 \%$. Hasil analisis menunjukkan bahwa tingkat penggunaan herbisida sudah efisien secara teknis. Rata-rata penggunaan herbisida yaitu sebesar 4.59 ltr/ha.

Selanjutnya, untuk mengetahui pengaruh dari masing-masing faktor produksi pada petani yang bukan peserta program SLPTT digunakan analisis regresi. Berdasarkan hasil analisis regresi pada lampiran diperoleh model hubungan antara luas lahan, tenaga kerja, pupuk urea, pupuk phonska, benih dan herbisida untuk yang bukan peserta program SLPTT, sebagai berikut:

$\mathrm{Y}=5.65+1.35$ Ln Luas lahan - 0.099 Ln Tenaga kerja +0.415 Ln Pupuk Urea - 0.025 Ln Pupuk Phonska +0.025 Ln Benih -0.011 Ln Herbisida

Model tersebut menunjukan bahwa, naiknya luas lahan cenderung menaikkan produksi. Hasil pengujian statistik menunjukkan pengaruh luas lahan terhadap produksi sangat nyata $(\mathrm{P}=0,000)$. Dimana naiknya luas lahan sebesar $1 \%$ akan menaikkan produksi sebesar $1,35 \%$. Tapi dalam hasil analisis terlihat bahwa tingkat penggunaan faktor produksi lahan belum efisien secara teknis. Ratarata penggunaan luas lahan pada petani yang bukan peserta adalah 1,158 ha.

Faktor produksi benih cenderung menaikkan produksi. Walaupun secara statistik menunjukkan pengaruh benih terhadap produksi tidak nyata $(\mathrm{P}=$ 0,849 ) namun hasil analisis menunjukkan bahwa penggunaan faktor produksi benih sudah efisien secara teknis. Dimana naikknya penggunaan benih sebesar $1 \%$ akan menaikkan produksi sebesar $0,025 \%$. Rata-rata penggunaan benih pada petani responden ialah $30,63 \mathrm{~kg} / \mathrm{ha}$, jika dibandingkan dengan anjuran penggunaan benih pada analisis usahatani jagung oleh Danarti dkk yaitu sebanyak $56 \mathrm{~kg} / \mathrm{ha}$, hal ini berarti bahwa penggunaan benih masih berada dibawah daripada anjuran. Jadi benih masih bisa ditambah untuk mendapatkan hasil yang lebih baik.

Faktor produksi tenaga kerja menunjukkan pengaruh yang negatif terhadap produksi $(\mathrm{P}=$ 0.313 ). Dimana naiknya tenaga kerja sebesar $1 \%$ akan mengurangi produksi sebesar $0.099 \%$. Hasil analisis menunjukkan bahwa tingkat penggunaan faktor produksi tenaga kerja sudah tidak efisien secara teknis. Rata-rata penggunaan tenaga kerja pada petani responden yaitu 61.94 HOK. Jika dibandingkan dengan anjuran penggunaan tenaga kerja yang ada pada analisis usahatani jagung oleh Danarti dkk yaitu sebesar $57 \mathrm{HOK}$, ini berarti penggunaan tenaga kerja pada usahatani jagung di Kecamatan Remboken relatif sudah berlebihan.

Faktor produksi pupuk khususnya pupuk urea cenderung menaikkan produksi. Hasil pengujian statistik menunjukkan pengaruh penggunaan pupuk urea terhadap produksi sangat nyata $(\mathrm{P}=0,011)$. Dimana naiknya penggunaan pupuk urea sebesar $1 \%$ akan menaikkan produksi sebesar $0,415 \%$. Hasil analisis menunjukkan bahwa tingkat penggunaan pupuk urea sudah efisien secara teknis. Ratarata penggunaan pupuk urea yaitu $131,8 \mathrm{~kg} / \mathrm{ha}$, jika dibandingkan dengan anjuran penggunaan pupuk urea pada analisis usahatani jagung oleh Danarti dkk yaitu sebesar $150 \mathrm{~kg} / \mathrm{ha}$, hal ini berarti penggunaan pupuk urea pada petani responden sudah melebihi dari anjuran yang diberikan.

Faktor produksi pupuk khususnya pupuk phonska cenderung mengurangi produksi. Hasil pengujian statistik menunjukkan pengaruh penggunaan pupuk phonska terhadap produksi tidak nyata $(\mathrm{P}=0,895)$. Naiknya penggunaan pupuk phonska sebesar $1 \%$ akan mengurangi produksi sebesar $0,025 \%$. Hasil analisis menunjukkan bahwa tingkat penggunaaan pupuk phonska sudah tidak efisien secara teknis. Rata-rata penggunaan pupuk phonska pada petani responden yaitu $113,3 \mathrm{~kg} / \mathrm{ha}$. 
Faktor produksi herbisida cenderung mengurangi produksi. Dalam pengujian secara statistik menunjukkan pengaruh herbisida terhadap produksi tidak nyata $(\mathrm{P}=0,919)$. Dimana naiknya penggunaan herbisida sebesar 1\% akan mengurangi produksi sebesar 0,011\%. Hasil analisis menunjukkan bahwa tingkat penggunaan herbisida sudah tidak efisien secara teknis. Rata-rata penggunaan herbisida yaitu sebesar 6,15 ltr/ha.

Untuk membandingkan tingkat efisiensi antara kelompok tani peserta program SLPTT dengan kelompok tani yang bukan peserta program SLPTT dilakukan pengujian dengan analisis regresi dengan menggunakan variabel dummy. Yang disajikan pada Tabel 4. Tabel 4 menunjukkan bahwa tingkat efisiensi penggunaan faktor produksi luas lahan, tenaga kerja, pupuk urea, benih dan herbisida tidak berbeda nyata antara peserta maupun yang bukan peserta $(\mathrm{P}>0,20)$. Tetapi tingkat efisiensi penggunaan faktor produksi pupuk phonska sangat berbeda nyata antara peserta maupun yang bukan peserta $(P=0,006)$. Penggunaan faktor produksi pupuk ponska oleh petani yang bukan peserta SLPTT.

Tabel 4. Hasil Analisis Regresi Fungsi Produksi Jagung di Kecamatan Remboken

\begin{tabular}{|l|r|r|r|r|}
\hline \multicolumn{1}{|c|}{ Predictor } & Coef & SE Coef & $\mathrm{T}$ & $\mathrm{P}$ \\
\hline Constant & 5,6501 & 0,6412 & 8,18 & 0,000 \\
\hline Ln Luas Lahan & 1,35311 & 0,08991 & 15,05 & 0,000 \\
\hline Ln TK & $-0,0987$ & 0,08970 & $-1,10$ & 0,275 \\
\hline Ln Urea & 0,4146 & 0,1446 & 2,87 & 0,005 \\
\hline Ln Phonska & $-0,0248$ & 0,1744 & $-0,14$ & 0,887 \\
\hline Ln Benih & 0,0249 & 0,1177 & 0,21 & 0,833 \\
\hline Ln Herbisida & $-0,0114$ & 0,1042 & $-0,11$ & 0,913 \\
\hline DLn Luas Lahan & $-0,0272$ & 0,2324 & $-0,12$ & 0,907 \\
\hline DLn TK & 0,0333 & 0,1524 & 0,22 & 0,827 \\
\hline DLn Urea & $-0,2586$ & 0,2037 & $-1,27$ & 0,208 \\
\hline DLn Phonska & 0,6315 & 0,2230 & 2,83 & 0,006 \\
\hline DLn Benih & 0,0760 & 0,3369 & 0,23 & 0,822 \\
\hline DLn Herbisida & 0,1891 & 0,1988 & 0,95 & 0,344 \\
\hline D & $-1,497$ & 1,213 & $-1,23$ & 0,221 \\
\hline
\end{tabular}

$\mathrm{S}=0,296228 \quad \mathrm{R}-\mathrm{Sq}=94,8 \%$

$\mathrm{R}-\mathrm{Sq}(\operatorname{adj})=940 \%$

\section{Efisiensi Penggunaan Faktor Produksi}

Hasil perhitungan efisiensi penggunaan faktorfaktor produksi khususnya untuk petani yang merupakan peserta program SLPTT dapat dilihat pada Tabel 5.
Tabel 5. Hasil Analisis Efisiensi Ekonomis Faktor Produksi Jagung Untuk Peserta Program SLPTT

\begin{tabular}{|c|l|c|c|}
\hline No & \multicolumn{1}{|c|}{ Variabel } & $\begin{array}{c}\text { Elastisitas } \\
\text { (bi) }\end{array}$ & NPMxi/Hxi \\
\hline 1 & Lahan & 1,35 & 10,92755 \\
\hline 2 & Tenaga Kerja & $-0,099$ & $-0,299634$ \\
\hline 3 & Pupuk Urea & 0,415 & 18,44634 \\
\hline 4 & Pupuk Phonska & 0,507 & 26,33773 \\
\hline 5 & Benih & 0,025 & 2,550171 \\
\hline 6 & Hebisida & $-0,011$ & $-0,335309$ \\
\hline
\end{tabular}

Tabel 5 menunjukkan bahwa secara teknis, penggunaan lahan belum efisien (Ep $>1)$, penggunaan pupuk urea, pupuk ponska dan benih oleh petani peserta SLPTT sudah efisien $(0<\mathrm{Ep}<1)$ sedangkan penggunaan factor produksi tenaga kerja dan herbisida tidak efisien $(\mathrm{Ep}<0)$

Analisis yang disajikan pada Tabel 5 menunjukkan bahwa untuk faktor produksi Lahan, pupuk urea, pupuk phonska, dan benih mempunyai nilai efisiensi lebih dari satu, artinya penggunaan faktor produksi tersebut belum mencapai tingkat efisien, maka untuk memperoleh tingkat keuntungan maksimum faktor produksi tersebut perlu ditambah.

Untuk faktor produksi tenaga kerja dan herbisida mempunyai nilai efisiensi yang lebih kecil dari satu artinya penggunaan faktor produksi tersebut telah melampaui titik efisiensi. Tidak efisiennya penggunaan tenaga kerja akibat tingginya upah tenaga kerja dan penggunaan tenaga kerja yang berlebihan.

Hasil perhitungan efisiensi penggunaan faktorfaktor produksi khususnya untuk petani yang bukan peserta program SLPTT dapat dilihat pada Tabel 6. Tabel 6 menunjukkan bahwa secara teknis penggunaan faktor produksi lahan belum efisien $(\mathrm{Ep}>1)$, penggunaan faktor produksi tenaga kerja, pupuk ponska dan herbisida oleh petani yang bukan peserta SLPTT sudah tidak efisien $(\mathrm{Ep}<0)$, sedangkan penggunaan pupuk urea dan benih sudah efisien $(0<\mathrm{Ep}<1)$. 
Tabel 6. Hasil Analisis Efisiensi Ekonomis Faktor Produksi Jagung Untuk yang Bukan Peserta Program SLPTT

\begin{tabular}{|c|l|c|c|}
\hline No. & \multicolumn{1}{|c|}{ Variabel } & $\begin{array}{c}\text { Elastisitas } \\
\text { (bi) }\end{array}$ & NPMxi/Hxi \\
\hline 1 & Lahan & 1,35 & 10,92755 \\
\hline 2 & Tenaga Kerja & $-0,099$ & $-0,299634$ \\
\hline 3 & Pupuk Urea & 0,415 & 18,44634 \\
\hline 4 & Pupuk Phonska & $-0,025$ & $-0,899249$ \\
\hline 5 & Benih & 0,025 & 2,550171 \\
\hline 6 & Hebisida & $-0,011$ & $-0,335309$ \\
\hline
\end{tabular}

Analisis yang disajikan dalam Tabel 6 menunjukkan bahwa untuk faktor produksi lahan, pupuk urea dan benih mempunyai nilai efisiensi lebih dari satu, ini menunjukkan bahwa penggunaan faktor produksi tersebut oleh petani yang bukan peserta SLPTTbelum efiisen, oleh karena itu untuk memperoleh tingkat keuntungan maksimum faktor produksi tersebut perlu ditambah.

Untuk faktor produksi tenaga kerja, pupuk phonska dan herbisida mempunyai nilai efisiensi kurang dari satu. Hal ini menunjukkan bahwa penggunaan faktor produksi tersebut oleh petani yang bukan peserta SLPTT telah berlebihani. Oleh karena itu untuk memperoleh tingkat keuntungan maksimum faktor produksi tersebut perlu dikurangi.

\section{KESIMPULAN DAN SARAN}

\section{Kesimpulan}

Berdasarkan hasil penelitian terhadap petani responden yang mengelola usahatani jagung baik yang merupakan peserta program maupun bukan peserta program SLPTT di Kecamatan Remboken, maka dapat disimpulkan sebagai berikut:

1. Faktor luas lahan, pupuk urea dan pupuk phonska berpengaruh terhadap produksi jagung pada petani peserta program SLPTT maupun bukan peserta SLPTT. Terdapat perbedaan pengaruh pupuk ponska terhadap produksi jagung antara peserta dan bukan peserta SLPTT.

2. Secara teknis, efisiensi penggunaan factor produksi lahan, pupuk urea, benih, tenaga kerja dan herbisida oleh petani peserta dan bukan peserta SLPTT adalah sama. kecuali penggunaan pupuk ponska. Penggunaan lahan belum efisien sedangkan penggunaan factor produksi tenaga kerja dan herbisida tidak efisien. Penggunaan faktor produksi pupuk ponska oleh petani peserta SLPTT sudah efisien sedangkan penggunaan pupuk tersebut oleh petani bukan peserta SLPTT tidak efisien.

3. Secara ekonomis, efisiensi penggunaan faktor produksi baik oleh petani peserta maupun bukan peserta SLPTT adalah sama kecuali penggunaan pupuk ponska. Penggunaan faktor produksi Lahan, pupuk urea, dan benih belum efisien, sedangkan penggunaan factor produksi tenaga kerja dan herbisida sudah tidak efisien. Penggunaan faktor produksi pupuk phonska oleh petani peserta SLPTT belum efisien sedangkan penggunaan faktor produksi tersebut oleh petani bukan peserta SLPTT tidak efisien

\section{Saran}

1. Penggunaan tenaga kerja dan herbisida perlu dikurangi baik oleh petani peserta maupun yang bukan peserta SLPTT. Penggunaan pupuk ponska oleh petani bukan peserta SLPTT perlu dikurangi.

2. Perlu ada penyuluhan tentang penggunaan faktor produksi yang sesuai untuk usahatani jagung di Kecamatan Remboken.

\section{DAFTAR PUSTAKA}

Apriyantono, A. 2008. Panduan Pelaksanaan Sekolah Lapang Pengelolaan Tanaman Terpadu (SL-PTT) Jagung.

BPS, 2010. Remboken Dalam Angka 2009. BPS SULUT.

BPS, 2010. Minahasa Dalam Angka 2009. BPS SULUT.

Hernanto, F. 1991. Ilmu Usahatani. Penebar Swadaya. Jakarta

.1995. Dasar Penyusunan Suatu Proyek..Pustaka Sinar Harapan. Jakarta

.1993.Prinsip Dasar Ekonomi Pertanian.Teori dan Aplikasi. Rajawali Pers, Jakarta 
2002.Teori Ekomoni Produksi. Rahardja,P.2008. Teori Ekonomi Mikro. FEUI. JaUI.Press.Jakarta karta.

Gorontalo.litbang.deptan.go.id. (Sekolah Lapang Pengelolaan Tanaman Terpadu (SL-PTT) Jagung). diakses September 2010.

Gerbangtani.blogspot.com.( Tolak ukur keberhasilan SLPTT). Diakses September 2010.

Gujarati. D. 1988. Ekonometrika Dasar. Erlangga. faperta-unswagati.com/pdf/pdfv5/3.pdf

Mosher, A. 1991. Menggerakan dan Membangun Pertanian. CV Yasaguna. Jakarta.

Mubyarto, 1989. Pengantar ekonomi pertanian. LP3ES, Jakarta.

Nugroho,W.2010.Teori Produksi Pertanian. http://images.twnugroho.multiply.multiplyco ntent.com. Diakses Juni 2010

Soekartawi, 1996. Analisis Usahatani. UI.Press.Jakarta.

Zulkifli,A.2009. Analisis Efisiensi Penggunaan Faktor-Faktor Produksi Pada Usaha tani jagung (Studi kasus petani jagung di Kel. Panreng Kec. Baranti Kab.Sidrap).

(http://www.tenangjaya.com/index.php/releva n-artikel/analisis-efisiensipenggunaan.htm).diakses September 2010.

Soekartawi, 1995. Analisis Usahatani. Universitas Indonesia, Jakarta 